J. Dairy Sci. 92:5147-5153

doi:10.3168/jds.2009-2245

(c) American Dairy Science Association, 2009.

\title{
Effects of fat concentration of a high-protein milk replacer on calf performance
}

\author{
T. M. Hill, ${ }^{1}$ H. G. Bateman II, J. M. Aldrich, and R. L. Schlotterbeck \\ Akey Nutrition and Research Center, PO Box 5002, Lewisburg, OH 45338
}

\section{ABSTRACT}

The hypothesis was that calves fed high-fat milk replacers (MR) would have reduced starter intake, digestibility, and average daily gain (ADG). Forty-eight Holstein calves (initially $42.4 \pm 1.5 \mathrm{~kg}$ of body weight, 2 to $3 \mathrm{~d}$ of age; 12 calves/treatment) were fed $0.66 \mathrm{~kg}$ dry matter (DM) of MR per calf daily that contained 14 , 17,20 , or $23 \%$ fat. This MR had crude protein (CP) to metabolizable energy (ME) ratios ranging from 51.6 to $56.7 \mathrm{~g}$ of $\mathrm{CP} / \mathrm{Mcal}$ of ME, which were above and below a previously determined optimum. Calves were weaned at $28 \mathrm{~d}$; postweaning measurements were continued to $\mathrm{d}$ 56. A $20 \%$ CP starter and water were fed ad libitum all $56 \mathrm{~d}$ of the trial. Measurements of digestion were made using chromic oxide as a marker in the MR and starter from fecal samples collected on d 19 to 23 from 4 calves/ treatment. Selected serum constituents were measured on $d$ 21. Calves were housed individually in pens bedded with straw within a naturally ventilated barn with no added heat. The average barn temperature was $2^{\circ} \mathrm{C}$. Data were analyzed as a completely randomized design using polynomial contrasts to separate differences in the means. Preweaning apparent digestibility of DM, organic matter, fat, nonfiber carbohydrates, $\mathrm{Ca}$, and $\mathrm{P}$ and serum amylase concentration were linearly reduced as fat increased from 14 to $23 \%$. Preweaning starter intake responded quadratically to fat, being lowest at 14 and $23 \%$ fat. A reduction in digestibility and starter intake contributed to less ADG at the higher fat concentrations in the MR. A $27 \% \mathrm{CP}, 17 \%$ fat MR with $55 \mathrm{~g}$ of $\mathrm{CP} /$ Mcal of ME maximized preweaning ADG when fat concentration was varied to obtain various $\mathrm{CP}$ to ME ratios in the MR. Additionally, a $27 \% \mathrm{CP}$, $20 \%$ fat MR with $53 \mathrm{~g}$ of CP/Mcal of ME supported overall ADG similar to calves fed the $17 \%$ fat MR but preweaning digestion measurements and serum amylase concentrations were less than in calves fed the $17 \%$ fat MR.

Key words: fat, protein, digestion, calf

\footnotetext{
Received March 26, 2009.

Accepted July 6, 2009

${ }^{1}$ Corresponding author: mhill@akey.com
}

\section{INTRODUCTION}

The CP and energy intake from milk replacer (MR) greatly affects calf ADG and carcass protein and fat deposition (Donnelly and Hutton, 1976; Blome et al., 2003; Bartlett et al., 2006). When CP is restricted or limited relative to energy consumed, the extra energy is stored as fat. Similarly, Tikofsky et al. (2001) reported that when MR equal in protein and energy are fed, energy from fat is more likely to result in fat deposition than energy from lactose. Bascom et al. (2007) reported a trend for less ADG when a high-protein MR with $33 \%$ fat was fed to calves compared with a high-CP MR with $16 \%$ fat; however, fat deposition was considerably greater in the calves fed the $33 \%$ fat MR. In the previously mentioned trials, calves were fed MR above their maintenance requirements (i.e., "accelerated" MR programs) and were not fed starter. When calves were fed starter and MR well over their maintenance requirements during cold temperatures in an unheated nursery, Hill et al. (2007b) reported that added energy from MR fat did not improve ADG, but added energy from MR lactose and CP improved ADG. Fat intake is a way to provide energy and reduce body fat loss during sub-thermoneutral temperatures; however, its application in calves fed close to maintenance requirements and housed in hutches during cold weather has yielded mixed results (Davis and Drackley, 1998).

A reason for the mixed results of increasing the nutrients fed via milk or MR is the balance between intake of nutrients from MR or milk and early-life calf growth with the development of the rumen, starter intake, and growth later in the calf's life. Numerous researchers have reported that feeding too much milk or MR will result in a postweaning reduction in ADG by depressing starter intake (Davis and Drackley, 1998; Hill et al., 2006a, 2007b). Terre et al. (2007) attributed a portion of the lower ADG to a lower digestion of starter in the calves fed the high versus low amount of MR. However, recently, Hill et al. (2009a) fed 27\% CP MR that contained either 17 or $31 \%$ fat and observed no change in starter intake but less ADG in calves fed the high-fat MR. The fatty acid profiles of these diets were confounded and might have explained the differ- 
ences in ADG because the fatty profile of the $26 \%$ fat MR appeared to be deficient in essential fatty acids. However, all of the fat in $31 \%$ fat MR and most of the fat in the $17 \%$ fat was edible lard, a saturated fat and the predominant source of fat used in MR in the United States.

Sabb et al. (1986) reported that pancreatic lipase activity in rats substantially declines when corn starch replaces fat at dietary fat concentrations below $23 \%$, especially if the fat is saturated. The fat concentration of the complete diet consumed by the calf fed MR and starter is typically declining with age because of increasing starter intake that is low in fat combined with an often fixed MR intake. Thus, lipase production could decline in the later preweaning period of the calf if lipase production in calves is as in rats. Data of this nature could not be found for calves.

In previous research, the optimum $\mathrm{CP}$ to energy ratios in MR-fed calves have ranged from 43 to $61 \mathrm{~g}$ of $\mathrm{CP} / \mathrm{Mcal}$ of ME, and the fat concentrations in the optimum MR treatments have ranged from 17.7 to 24.2\% (Donnelly and Hutton, 1976; Blome et al., 2003; Bartlett et al., 2006; Hill et al., 2009b). Of these trials, only Hill et al. (2009b) fed starter, weaned the calves, and measured postweaning performance. They fed $17 \%$ fat MR ranging from 23 to $29 \% \mathrm{CP}$ at either 0.545 or $0.654 \mathrm{~kg}$ of DM. Calf ADG was maximized with the $27 \% \mathrm{CP}, 17 \%$ fat MR fed at $0.654 \mathrm{~kg}$ of DM (55 g of $\mathrm{CP} /$ Mcal of ME).

With these data in mind, a trial was designed to compare MR containing $27 \% \mathrm{CP}$ and fed at $0.66 \mathrm{~kg}$ of DM daily with fat concentrations of $14,17,20$, and $23 \%$. These fat concentrations are below and above the range fed in previous trials, and fat concentration was altered using edible lard. The objective was to measure calf performance and digestion of the diets using fat to vary energy intake and the $\mathrm{CP}$ to energy ratio of the MR while offering starter and weaning the calves. Calves were fed $0.66 \mathrm{~kg}$ DM of a $27 \% \mathrm{CP}$ MR ranging from 14 to $23 \%$ fat. Calves were managed in an unheated nursery $\left(2^{\circ} \mathrm{C}\right)$ that was below the thermoneutral zone of calves when additional fat intake might have more benefit to the calves than if in conditions above thermoneutral temperatures. Our hypothesis was that high fat concentrations would depress starter intake, digestibility of starter DM, and ADG.

\section{MATERIALS AND METHODS}

This trial compared $4 \mathrm{MR}$ differing in concentrations of fat $(14,17,20$, and $23 \%$ fat on a DM basis; Table 1 ). The MR contained $27 \% \mathrm{CP}$. Fat in the MR was increased by adding edible lard from a 7.2\% CP, $61.8 \%$ fat powder (LOL Milk Products, Black River Falls, WI) to replace whey $(12.8 \% \mathrm{CP}, 0.7 \%$ fat $)$ and whey protein concentrate $(80.9 \% \mathrm{CP}, 5.4 \%$ fat $)$. The MR were fed at $0.681 \mathrm{~kg}$ of as-fed $(0.660 \mathrm{~kg}$ of $\mathrm{DM})$ powder daily. Calves were fed their MR halved into a.m. and p.m. feedings for $25 \mathrm{~d}$, followed by only the a.m. feeding (half their previous MR) on d 26, 27, and 28. The MR were reconstituted at the rate of $134 \mathrm{~g}$ of powder into a volume of $1 \mathrm{~L}$ with warm water. Calves were fed a pelleted calf starter (formulated for DM basis 20.7\% CP, analyzed $22.3 \%$ CP; Table 1) and fresh water ad libitum. This trial used 48 Holstein bull calves (12/ treatment) $<1$ wk of age from one dairy farm. (From 20 similar, low variance trials in our research nursery, a power analysis using residual error mean squares and means predicted an $11 \%$ difference in means could be separated at $P<0.05$ with 12 calves per treatment.) Calves were received at approximately $1100 \mathrm{~h}$ after a 3.5 -h transit. Calves were fed the $21 \%$ fat MR at the p.m. feeding and following a.m. feeding. At $1100 \mathrm{~h}$ on the day after arrival the calves were weighed (initial BW), blood was sampled from the jugular vein to measure serum protein using an optical refractometer (Atago USA Inc., Bellevue, WA), and calves were randomly assigned to treatment (d 0 ).

The MR and starter were formulated to contain $0.25 \%$ chromic oxide (as-fed basis). The basis was to achieve an intake of approximately $2 \mathrm{~g}$ of chromic oxide per calf daily, exceeding the minimum suggested $1 \mathrm{~g} /$ calf daily for digestibility estimates (Bouchard et al., 1973). Fecal grab samples were taken from 4 calves randomly selected per treatment on d 19 to 23, frozen daily, combined on an equal wet-weight basis, and subsampled for analysis. Twelve fecal grab samples per calf accounting for the majority of the defecation initiated by palpation were taken to account for 2-h intervals of the 24-h day by rotating sampling times over the 5 -d collection period. Approximately $110 \%$ of the estimated feeds needed for each treatment were manufactured as single batches. Equal samples of manufactured feeds were collected from every second bag $(22.7 \mathrm{~kg})$ of feed at the time of manufacturing and composited. Composites of feed and feeds were analyzed (AOAC, 2000) for DM (oven method 930.15), ash (oven method 942.05), CP (Kjeldahl; method 988.05), and Ca, P, K, Mg (dry ashing, acid digestion, analysis by inductively coupled plasma spectrometry; method 985.01), and $\mathrm{Cr}$ (AOAC, 2000; method 993.14). Additionally, the starter was analyzed for NDF with ash by the procedure of Van Soest et al. (1991) without sodium sulfite or $\alpha$-amylase, and ADF with ash (Robertson and Van Soest, 1981). Measured concentrations of $\mathrm{Cr}$ and other nutrients in the feed, feed intake, and $\mathrm{Cr}$ and other nutrient concentrations in the feces were used to estimate fecal output and apparent digestibility. On d 21, to correspond with 
FAT CONCENTRATION OF A CALF MILK REPLACER

Table 1. Nutrient concentrations (DM basis) of the milk replacers (MR) and starter

\begin{tabular}{|c|c|c|c|c|c|}
\hline Item & $14 \%$ fat $\mathrm{MR}$ & $17 \%$ fat $\mathrm{MR}$ & $20 \%$ fat $\mathrm{MR}$ & $23 \%$ fat MR & Starter \\
\hline \multicolumn{6}{|l|}{ Analyzed, \% } \\
\hline DM & 97.12 & 97.08 & 97.04 & 97.01 & 87.30 \\
\hline $\mathrm{CP}$ & 26.82 & 26.84 & 26.88 & 26.92 & 22.34 \\
\hline Fat & 14.41 & 17.49 & 20.59 & 23.72 & 4.48 \\
\hline $\mathrm{ADF}$ & - & - & - & - & 6.29 \\
\hline $\mathrm{NDF}$ & - & - & - & - & 10.43 \\
\hline Ash & 6.17 & 6.08 & 5.99 & 5.95 & 6.71 \\
\hline $\mathrm{Ca}$ & 0.722 & 0.718 & 0.714 & 0.710 & 1.26 \\
\hline $\mathrm{P}$ & 0.530 & 0.516 & 0.503 & 0.490 & 0.581 \\
\hline \multicolumn{6}{|l|}{ Calculated } \\
\hline $\mathrm{NFC}^{1}$ & 52.60 & 49.59 & 46.54 & 43.41 & 56.08 \\
\hline $\mathrm{ME}, \mathrm{Mcal} / \mathrm{kg}^{2}$ & 4.73 & 4.89 & 5.05 & 5.22 & 3.67 \\
\hline $\mathrm{g}$ of $\mathrm{CP} / \mathrm{Mcal}$ of $\mathrm{ME}$ & 56.7 & 54.9 & 53.2 & 51.6 & 60.9 \\
\hline
\end{tabular}

${ }^{1} 100-(\mathrm{CP}+$ fat $+\mathrm{NDF}+$ ash $)$.

${ }^{2}$ Using NRC (2001) equations.

the fecal collection period, a venous blood sample was taken from each calf in a test tube without preservatives or anticoagulants, separated by centrifugation, and analyzed for albumin, alkaline phosphatase, amylase, creatinine, glucose, total protein, and urea-N, all as described by Hill et al. (2007a), Ca (Michaylova and Ilkova, 1971), and P (Tedokon et al., 1992).

Calves were weighed every $7 \mathrm{~d}$ until the end of the trial (d 56). Dry feed offered and feed refusals were weighed daily. Fecal scores were assigned daily based on a 1 to 5 system ( 1 being normal, thick in consistency; 2 being normal, but less thick; 3 being abnormally thin but not watery; 4 being watery; 5 being watery with abnormal coloring; modified from Kertz and Chester-Jones, 2004) while calves were in individual pens. Hip widths were measured with a caliper and BCS of calves were measured during the initial (d 0) measurement period and every 14-d thereafter. A 1 to 5 system using 0.25 -unit increments with 1 being emaciated and 5 being obese was used for BCS (Wildman et al., 1982). Scores were based on changes around the vertical and transverse processes of the spine as palpated by one experienced technician and ranged from 1.5 to 3.5. The trial lasted $56 \mathrm{~d}$ and was conducted during the months of January through March. The average ambient temperature inside the barn during the trial was $2^{\circ} \mathrm{C}$ and ranged from -10 to $20^{\circ} \mathrm{C}$ based on hourly measurements.

Calves were housed in $1.2-\times 2.4-\mathrm{m}$ individual pens within a curtain sidewall barn with no added heat. The pens were bedded with long straw. Calves were cared for by acceptable practices as described in the Guide for the Care and Use of Agricultural Animals in Agricultural Research and Teaching (FASS, 1999). Calves received an intranasal tissue sensitive respiratory disease vaccine (TSV-2, Pfizer, Exton, PA) and subcutaneous injections of vitamins A, D, E (Vital E - A + D, ScheringPlough Animal Health, Union, NJ) and Se (MU-SE,
Schering-Plough Animal Health) upon arrival. Calves received an intramuscular respiratory disease vaccine (Bovashield Gold 5, Pfizer) at d 7 and again at d 28. At d 14 they received an intramuscular vaccine for types C and D clostridium (Ultra Choice 7, Pfizer). A pasteurella vaccine (Presponse HM, Fort Dodge, Fort Dodge, IA) was administered intramuscularly on d 28 and 42. Calves were castrated and dehorned at $36 \mathrm{~d}$ of age. Animals that required medication for sickness were treated per veterinary recommendation, and treatments were recorded daily. Scouring was the only sickness observed and it was diagnosed based on rectal temperatures $>39.5^{\circ} \mathrm{C}$, lack of vitality, and fecal scores $>2$ and treated with subcutaneous ceftiofur sodium (Naxcel, Pharmacia \& Upjohn, Kalamazoo, MI).

Data were analyzed using the MIXED procedure in SAS (Version 8, SAS Institute Inc., Cary, NC) as a completely randomized design. Calf within treatment was a random effect used to test the fixed effect of treatment. Day was a repeated measure using an autoregressive type 1 covariance structure within preweaning and postweaning periods. Linear, quadratic, and cubic polynomials were constructed to test for differences among the treatment means. Data reported are least squares means. The experimental unit was calf. Statistical significant differences are discussed at $P<0.05$, and trends were mentioned when $P<0.10$.

\section{RESULTS}

The starter was intended to be $20.7 \% \mathrm{CP}$, DM basis, but analyzed slightly higher (22.3\% CP, DM basis). Initial calf measurements did not differ $(P>0.05)$. No cubic contrasts were significant for any measurement.

During the digestion phase (d 19 to 23) using 4 of the 12 calves per treatment, intake of fat increased and intake of NFC decreased linearly $(P<0.05)$ as 
Table 2. Intake and apparent total-tract digestibility of nutrients in the 16 calves fed $27 \% \mathrm{CP}$ milk replacer (MR) with 4 concentrations of fat as determined on d 19 to 23 (DM basis)

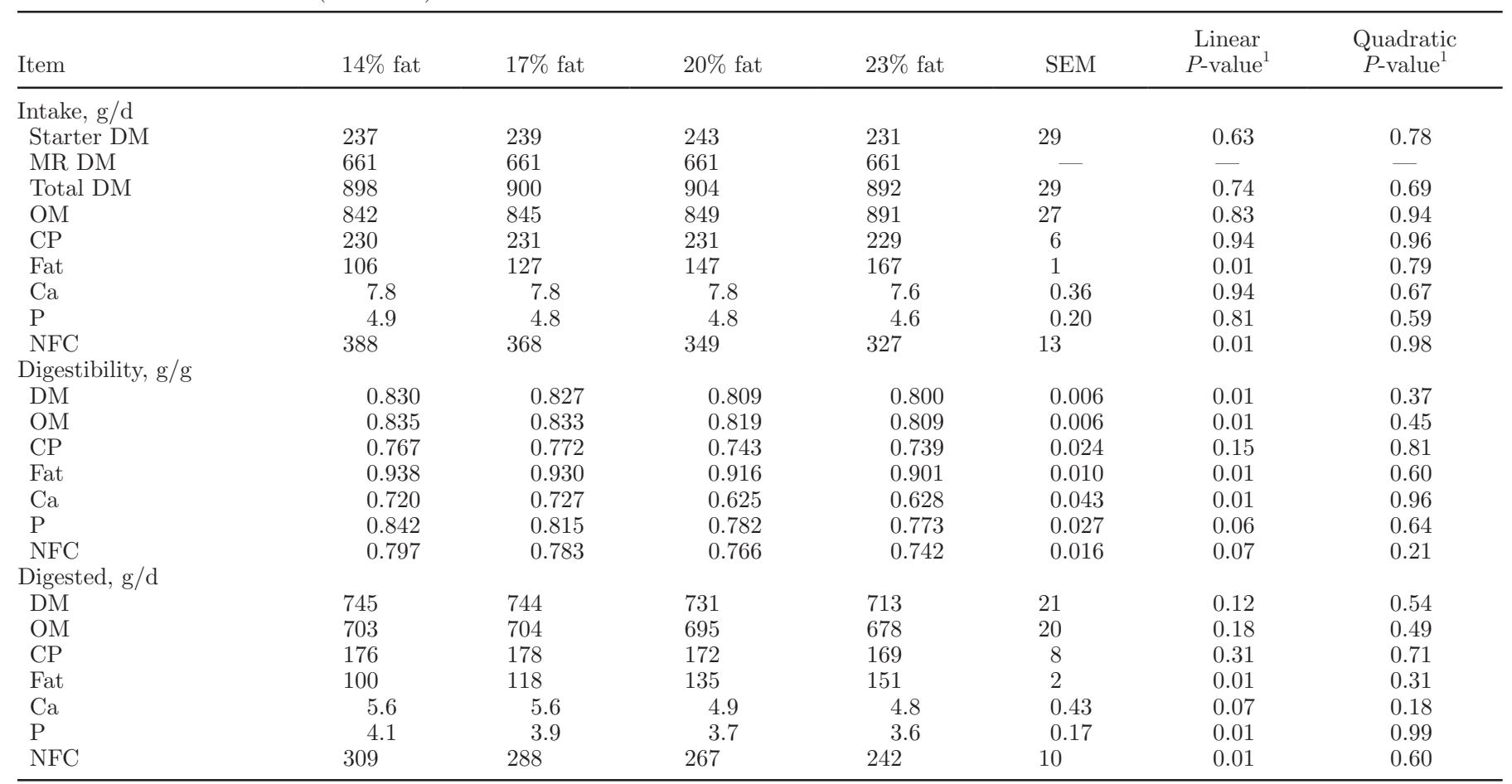

${ }^{1}$ Cubic contrasts were not significant $(P>0.20)$.

fat concentration in the MR increased (Table 2). The apparent digestibility of DM, OM, fat, and Ca decreased linearly $(P<0.05)$ as the concentration of fat increased in the MR. The apparent digestibility of $\mathrm{P}$ and NFC tended $(P<0.10)$ to decrease linearly as the concentration of fat increased in the MR. The amount of fat digested increased and the amounts of $\mathrm{P}$ and NFC digested decreased linearly $(P<0.05)$ as the concentration of fat increased in the MR. The amount of Ca digested tended $(P<0.10)$ to decrease linearly as the concentration of fat increased in the MR. Serum amylase concentrations (taken on d 21) decreased linearly $(P<0.05)$ as fat concentration increased in the
MR (Table 3). Serum Ca and P concentrations tended $(P<0.10)$ to decrease linearly as the concentration of fat increased in the MR.

Calf ADG responded in a quadratic manner $(P$ $<0.05)$ to fat concentration in the MR (Table 4). Preweaning (d 0 to 28) and overall (d 0 to 56) ADG were greatest in calves fed the 17 to $20 \%$ fat MR and lowest in calves fed the $23 \%$ fat MR. Postweaning (d 28 to 56 ) and overall ADG were unchanged between 14 and $20 \%$ fat and lowest for calves fed the MR with $23 \%$ fat. Preweaning starter intake responded quadratically $(P<0.05)$ to fat concentration in the MR increasing from 14 to $20 \%$ fat, but decreasing to $23 \%$ fat.

Table 3. Selected serum constituents in 48 calves fed $27 \%$ CP milk replacer with 4 concentrations of fat as determined on d 21

\begin{tabular}{|c|c|c|c|c|c|c|c|}
\hline Item & $14 \%$ fat & $17 \%$ fat & $20 \%$ fat & $23 \%$ fat & SEM & $\begin{array}{l}\text { Linear } \\
P \text {-value }\end{array}$ & $\begin{array}{l}\text { Quadratic } \\
P \text {-value }\end{array}$ \\
\hline Alkaline phosphatase, $\mathrm{U} / \mathrm{L}$ & 215 & 217 & 208 & 183 & 41 & 0.17 & 0.28 \\
\hline Amylase, U/L & 63 & 61 & 46 & 25 & 6.9 & 0.01 & 0.32 \\
\hline Urea nitrogen, mmol/L & 3.0 & 3.0 & 3.3 & 3.5 & 0.27 & 0.19 & 0.18 \\
\hline Total protein, $\mathrm{g} / \mathrm{L}$ & 57 & 57 & 57 & 58 & 2.6 & 0.90 & 0.99 \\
\hline Creatinine, $\mu \mathrm{mol} / \mathrm{L}$ & 80 & 76 & 71 & 66 & 6.8 & 0.14 & 0.63 \\
\hline Phosphorus, mmol/L & 3.03 & 2.97 & 2.94 & 2.90 & 0.057 & 0.09 & 0.34 \\
\hline
\end{tabular}

${ }^{1}$ Cubic contrasts were not significant $(P>0.20)$. 
Table 4. Performance of 48 calves fed $27 \%$ CP milk replacers with 4 different concentrations of fat

\begin{tabular}{|c|c|c|c|c|c|c|c|}
\hline Item & $14 \%$ fat & $17 \%$ fat & $20 \%$ fat & $23 \%$ fat & SEM & $\begin{array}{c}\text { Linear } \\
P \text {-value }\end{array}$ & $\begin{array}{l}\text { Quadratic } \\
P \text {-value }\end{array}$ \\
\hline Initial serum protein, $\mathrm{mg} / \mathrm{dL}$ & 4.6 & 4.4 & 4.5 & 4.7 & 0.15 & 0.29 & 0.31 \\
\hline Initial BW, kg & 42.3 & 42.7 & 42.3 & 42.4 & 1.49 & 0.34 & 0.64 \\
\hline 0 to $28 \mathrm{~d}$ & 0.334 & 0.364 & 0.353 & 0.315 & 0.020 & 0.22 & 0.04 \\
\hline 28 to $56 \mathrm{~d}$ & 0.728 & 0.715 & 0.719 & 0.658 & 0.032 & 0.09 & 0.05 \\
\hline 0 to $56 \mathrm{~d}$ & 0.531 & 0.540 & 0.536 & 0.486 & 0.022 & 0.12 & 0.04 \\
\hline 28 to $56 \mathrm{~d}$ & 1.547 & 1.489 & 1.529 & 1.381 & 0.107 & 0.28 & 0.13 \\
\hline 0 to $56 \mathrm{~d}$ & 0.849 & 0.837 & 0.861 & 0.769 & 0.059 & 0.31 & 0.19 \\
\hline \multicolumn{8}{|l|}{ Milk replacer intake, $\mathrm{kg} / \mathrm{d}$} \\
\hline 0 to $28 \mathrm{~d}$ & 0.626 & 0.626 & 0.626 & 0.626 & - & - & - \\
\hline 28 to $56 \mathrm{~d}$ & - & - & - & - & - & - & - \\
\hline 0 to $56 \mathrm{~d}$ & 0.313 & 0.313 & 0.312 & 0.312 & - & - & - \\
\hline \multicolumn{8}{|l|}{ Feed efficiency } \\
\hline 28 to $56 \mathrm{~d}$ & 1.5 & 1.5 & 1.5 & 1.6 & 0.09 & 0.82 & 0.94 \\
\hline 0 to $56 \mathrm{~d}$ & 1.8 & 1.8 & 1.8 & 1.8 & 0.08 & 0.61 & 0.68 \\
\hline \multicolumn{8}{|l|}{ Abnormal fecal days, ${ }^{2} \mathrm{n}$} \\
\hline 0 to $28 \mathrm{~d}$ & 0.6 & 0.7 & 0.5 & 0.7 & 0.31 & 0.22 & 0.26 \\
\hline 28 to $56 \mathrm{~d}$ & 0 & 0 & 0 & 0 & - & - & - \\
\hline 0 to $56 \mathrm{~d}$ & 0.6 & 0.7 & 0.5 & 0.7 & 0.31 & 0.36 & 0.39 \\
\hline \multicolumn{8}{|l|}{$\mathrm{BCS}^{3}$} \\
\hline Initial & 2.3 & 2.2 & 2.3 & 2.2 & 0.04 & 0.74 & 0.69 \\
\hline 0 to $28 \mathrm{~d}$ change & 0.1 & 0.2 & 0.1 & 0.2 & 0.04 & 0.69 & 0.55 \\
\hline 28 to $56 \mathrm{~d}$ change & 0.2 & 0.1 & 0.2 & 0.1 & 0.07 & 0.73 & 0.78 \\
\hline 0 to $56 \mathrm{~d}$ change & 0.3 & 0.3 & 0.3 & 0.3 & 0.06 & 0.99 & 0.98 \\
\hline \multicolumn{8}{|l|}{ Hip width, $\mathrm{cm}$} \\
\hline Initial & 17.3 & 17.6 & 18.1 & 17.6 & 0.32 & 0.25 & 0.21 \\
\hline 0 to $28 \mathrm{~d}$ change & 0.9 & 1.1 & 0.9 & 0.9 & 0.17 & 0.34 & 0.15 \\
\hline
\end{tabular}

${ }^{1}$ Cubic contrasts were not significant $(P>0.10)$.

${ }^{2}$ Fecal score system: $1=$ normal, thick in consistency; $2=$ normal, but less thick; $3=$ abnormally thin but not watery; $4=$ watery; $5=$ watery with abnormal coloring. Abnormal fecal days were days with fecal scores $>2$.

${ }^{3} 1$ to 5 system based on Wildman et al. (1982).

\section{DISCUSSION}

In each period (pre- and postweaning and overall) the calves fed the $23 \%$ fat MR had the lowest ADG. Both starter intake and digestion of nutrients were involved because calves fed the $23 \%$ fat MR had the lowest intake and lowest digestion of several major nutrients. The reduction in Ca digestibility and amount of $\mathrm{P}$ digested as fat increased in the $\mathrm{MR}$ is consistent with results in other species (French and Elliot, 1943; Calverley and Kennedy, 1947) and calves (Toullec et al., 1980), especially when saturated fats were fed (Yacowitz et al., 1967).

Guilloteau et al. (1985) reported that lipase was greatest in the milk fed calf and decreased as starter consumption increased during weaning and postweaning. Because digestion measures were made on d 19 to 23 in the current trial, before weaning at d 28, lipase production could have been declining and have contributed to the reductions in fat digestion that were measured. Sabb et al. (1986) reported that rat pancreatic lipase activity was not linearly related to lipid intake and lipase activity differs relative to the lipid content and type in the diet. They reported no difference in lipase activity from diets with 5 to $20 \%$ fat but large increases in activity with diets containing 23 and $29 \%$ fat. Additionally, rats fed diets with saturated fat had much lower lipase activities than unsaturated fat diets at $17 \%$ fat. In the current trial, during d 19 to 23 when the digestion measures were made, the total dietary fat (predominantly saturated fat from lard) ranged from 11 to $18 \%$, diluted by starter intake, from MR treatments that ranged from 14 to $23 \%$ fat.

The decrease in serum amylase concentrations, starter intake, and digestion of NFC with increasing fat intake is consistent with measures of amylase activities in the 
intestine of calves and rats. Amylase was lowest in the milk-fed calf and increased as starter consumption increased during weaning and postweaning (Guilloteau et al., 1985). In rats, amylase activity was directly related to carbohydrate intake (Thornburg et al., 1987; Sankaran et al., 1992) and declined with the intake of fat (Forman and Schneeman, 1980).

The quadratic response of starter intake to MR fat concentration preweaning could have attributed to some of the differences in ADG. Consumption of concentrates by calves stimulates the microbial population of the rumen and their end-products that initiate rumen epithelial development (Hibbs et al., 1956; Warner et al., 1956), which could have contributed to the increased digestion measurements observed at lower fat intakes.

Maximal ADG at 17 to $20 \%$ fat is consistent with results from previous studies that tested the concentration of fat in MR fed at the same rate and fed to calves weaned at $42 \mathrm{~d}$ and reported maximal ADG and starter intake with $17 \%$ fat (Hill et al., 2006b). Postweaning performance did not differ $(P>0.05)$ and differed little numerically among calves fed the 14, 17, and $20 \%$ fat MR, but ADG was the lowest for calves fed the $23 \%$ fat MR.

A MR with $27 \% \mathrm{CP}, 17 \%$ fat, and $55 \mathrm{~g}$ of CP/Mcal of ME maximized preweaning ADG in this trial, where fat level was varied, and in a previous trial (Hill et al., 2009b), where CP was varied; however, the MR with $27 \% \mathrm{CP}, 20 \%$ fat, and $53 \mathrm{~g}$ of $\mathrm{CP} /$ Mcal of $\mathrm{ME}$ supported overall ADG similar to the $17 \%$ fat MR. In each trial, starter was fed and the calves were weaned, and postweaning ADG and starter intake were lowest in calves fed the $23 \%$ fat MR. The 53 to $55 \mathrm{~g}$ of CP/ Mcal of ME in the MR is less than $61.2 \mathrm{~g}$ of $\mathrm{CP} /$ Mcal of $\mathrm{ME}$ in the MR to maximize ADG as reported by Donnelly and Hutton (1976). However, 95\% of their ADG response occurred between 35.7 (their low) and $49.4 \mathrm{~g}$ of $\mathrm{CP} / \mathrm{Mcal}$ of ME MR and only $5 \%$ of the ADG response between 49.4 and 61.2 (their high) $\mathrm{g}$ of $\mathrm{CP} /$ Mcal of ME MR. Bartlett et al. (2006) reported 48.6 $\mathrm{g}$ of $\mathrm{CP} / \mathrm{Mcal}$ of $\mathrm{ME}$ and Blome et al. (2003) reported $51.7 \mathrm{~g}$ of $\mathrm{CP} /$ Mcal of ME per unit of $\mathrm{BW}$ to maximize ADG per unit BW. Calves in the trials of Donnelly and Hutton (1976), Blome et al. (2003), and Bartlett et al. (2006) were more than $14 \mathrm{~d}$ of age at the start of the trials, were on trial for 35 to $49 \mathrm{~d}$, and were fed only MR (no starter). Calves in the current trial and Hill et al. (2009b) were 2 to $3 \mathrm{~d}$ old initially and fed MR for 28 $\mathrm{d}$ and starter for the entire trial. A younger calf age and feeding starter might account for an apparent greater $\mathrm{CP}$ to $\mathrm{ME}$ ratio to maximize ADG.

\section{CONCLUSIONS}

Preweaning digestion of DM, OM, fat, NFC, Ca, and $\mathrm{P}$ and serum amylase concentration were linearly reduced as fat increased from 14 to $23 \%$ in a $27 \%$ CP milk replacer powder fed at $0.660 \mathrm{~kg}$ of $\mathrm{DM} /$ calf daily. Preweaning starter intake responded quadratically to fat, being lowest at 14 and $23 \%$ fat. A reduction in digestion and starter intake contributed to less ADG at the higher fat concentrations of the MR. A $27 \%$ CP, $17 \%$ fat MR with $55 \mathrm{~g}$ of $\mathrm{CP} / \mathrm{Mcal}$ of ME maximized preweaning ADG when fat concentration was varied, consistent with previous results when $\mathrm{CP}$ was varied to obtain various $\mathrm{CP}$ to $\mathrm{ME}$ ratios in the MR. Additionally, a $27 \% \mathrm{CP}, 20 \%$ fat MR with $53 \mathrm{~g}$ of CP/Mcal of ME supported overall ADG similar to calves fed the $17 \%$ fat MR, but preweaning digestion measurements and serum amylase concentrations were less than in calves fed the $17 \%$ fat MR.

\section{REFERENCES}

AOAC. 2000. Official Methods of Analysis. Vol. I. 17th ed. Association of Official Analytical Chemists, Arlington, VA.

Bartlett, K. S., F. K. McKeith, M. J. VandeHaar, G. E. Dahl, and J. K. Drackley. 2006. Growth and body composition of dairy calves fed milk replacers containing different amounts of protein at two feeding rates. J. Anim. Sci. 84:1454-1467.

Bascom, S. A., R. E. James, M. L. McGilliard, and M. Van Amburgh. 2007. Influence of dietary fat and protein on body composition of Jersey bull calves. J. Dairy Sci. 90:5600-5609.

Blome, R. M., J. K. Drackley, F. K. McKeith, M. F. Hutjens, and G. C. McCoy. 2003. Growth, nutrient utilization, and body composition of dairy calves fed milk replacers containing different amounts of protein. J. Anim. Sci. 81:1641-1655.

Bouchard, R., G. J. Brisson, and J. P. Julien. 1973. Nutritive value of bacterial sludge and whey powders for protein in calf milk replacers and on chromic oxide as indicator of digestibility. J. Dairy Sci. 56:1445-1449.

Calverley, C. E., and C. Kennedy. 1947. The effect of fat on calcium and phosphorus metabolism in normal growing rats under a normal dietary regime. J. Nutr. 33:165-175.

Davis, C. L., and J. K. Drackley. 1998. Effect of changes in environmental temperature and energy metabolism. Pages 79-89 in The Development, Nutrition, and Management of the Young Calf. Iowa State Univ. Press, Ames.

Donnelly, P. E., and J. B. Hutton. 1976. Effects of dietary protein and energy on the growth of Friesian bull calves. I. Food intake, growth, and protein requirements. N. Z. J. Agric. Res. 19:289-297.

FASS. 1999. Guide for the Care and Use of Agricultural Animals in Agricultural Research and Teaching. 1st rev. ed. Federation of Animal Science Societies, Savoy, IL.

Forman, L. P., and B. O. Schneeman. 1980. Effects of dietary pectin and fat on the small intestinal contents and exocrine pancreas of rats. J. Nutr. 110:1992-1999.

French, C. E., and R. F. Elliot. 1943. The interrelation of calcium and fat utilization. J. Nutr. 25:17-21.

Guilloteau, P., T. Corring, R. Toullec, and R. Guilhermet. 1985. Enzyme potentialities of the abomasums and pancreas of the calf. II. Effects of weaning and feeding a liquid supplement to ruminant animals. Reprod. Nutr. Dev. 25:481-493. 
Hibbs, J. W., H. R. Conrad, W. D. Pounden, and N. Frank. 1956. A high roughage system for raising calves based on early development of rumen function. VI. Influence of hay to grain ratio on calf performance, rumen development, and certain blood changes. J. Dairy Sci. 39:171-179.

Hill, T. M., J. M. Aldrich, R. L. Schlotterbeck, and H. G. Bateman II. 2006a. Effects of feeding calves different rates and protein concentrations of twenty percent fat milk replacers on growth during the neonatal period. Prof. Anim. Sci. 22:252-260.

Hill, T. M., J. M. Aldrich, R. L. Schlotterbeck, and H. G. Bateman II. 2006b. Effects of feeding rate and concentrations of protein and fat of milk replacers fed to neonatal calves. Prof. Anim. Sci. $22: 374-381$

Hill, T. M., J. M. Aldrich, R. L. Schlotterbeck, and H. G. Bateman II. 2007a. Amino acids, fatty acids, and fat sources for calf milk replacers. Prof. Anim. Sci. 23:401-408.

Hill, T. M., H. G. Bateman II, J. M. Aldrich, and R. L. Schlotterbeck. $2007 \mathrm{~b}$. Effects of the feeding rate of high protein calf milk replacers. Prof. Anim. Sci. 23:649-655.

Hill, T. M., H. G. Bateman II, J. M. Aldrich, and R. L. Schlotterbeck. 2009a. Effect of consistency of nutrient intake from milk and milk replacer on dairy calf performance. Prof. Anim. Sci. 25:85-92.

Hill, T. M., H. G. Bateman II, J. M. Aldrich, and R. L. Schlotterbeck. 2009b. Optimizing nutrient ratios in milk replacers for calves less than five weeks of age. J. Dairy Sci. 92:3281-3291.

Kertz, A. F., and H. Chester-Jones. 2004. Invited Review: Guidelines for measuring and reporting calf and heifer experimental data. J. Dairy Sci. 87:3577-3580.

Michaylova, V., and P. Ilkova. 1971. Photometric determinations of micro amounts of calcium with arsenazo III. Anal. Chim. Acta 53:194-198.

NRC. 2001. Nutrient Requirements of Dairy Cattle. 7th rev. ed. Natl. Acad. Sci., Washington, DC.

Robertson, J. B., and P. J. Van Soest. 1981. The Detergent System of Analysis and its Application to Human Foods. Cornell University, Ithaca, NY.

Sabb, J. E., P. M. Gadfrey, and P. M. Brannon. 1986. Adaptive response to rat pancreatic lipase to dietary fat: Effects of amount and type of fat. J. Nutr. 116:892-899.
Sankaran, H., C. W. Deveney, E. C. Larkin, and G. A. Rao. 1992. Carbohydrate intake determines pancreatic acinar amylase activity and release despite chronic alcoholemia in rats. J. Nutr. 122:1884-1891.

Tedokon, M., K. Suzuki, Y. Kayamori, S. Fujita, and Y. Katayama. 1992. Enzymatic assay of inorganic phosphate with use of sucrose phosphorylase and phosphoglucomatase. Clin. Chem. 38:512515

Terre, M., M. Devant, and A. Bach. 2007. Effect of level of milk replacer fed to Holstein calves on performance during the preweaning period and starter digestibility at weaning. Livest. Sci. 110:82-88.

Thornburg, W., J. Grimes, T. Goda, S. Bustamante, P. Pollack, and O. Koldovsky. 1987. Response of activity of jejunal disaccharides and pancreatic amylase in young and middle aged rats to a high carbohydrate diet. J. Nutr. 117:63-69.

Tikofsky, J. N., M. E. Van Amburgh, and D. A. Ross. 2001. Effect of varying carbohydrate and fat content of milk replacer on body composition of Holstein bull calves. J. Anim. Sci. 79:2260-2267.

Toullec, R., M. Theriez, and P. Thivend. 1980. Milk replacers for calves and lambs. World Anim. Rev, 33:32-42.

Van Soest, P. J., J. B. Robertson, and B. A. Lewis. 1991. Methods for dietary fiber, neutral detergent fiber, non-starch polysaccharides in relation to animal nutrition. Symposium: Carbohydrate methodology, metabolism and nutritional implications in dairy cattle. J. Dairy Sci. 74:3583-3597.

Warner, R. G., W. P. Flatt, and J. K. Loosli. 1956. Dietary factors influencing the development of the animal's stomach. J. Agric. Food Chem. 4:788-792.

Wildman, E. E., G. M. Jones, P. E. Wagner, R. L. Bowman, H. F. Troutt Jr., and T. N. Lesch. 1982. A dairy cow body condition scoring system and its relationship to selected production characteristics. J. Dairy Sci. 65:495-501.

Yacowitz, H., A. I. Fleischman, R. T. Amsden, and M. L. Bierenbaum. 1967. Effect of dietary calcium upon lipid metabolism in rats fed saturated or unsaturated fat. J. Nutr. 92:389-392. 